\title{
Study on the Anti-Inflammatory Activity and Mechanism of Medicinal Plants Used in the Treatment of Arthritis
}

\author{
Yoo-Hyun Kim, Ho Park \\ Department of Clinical Laboratory Science, Wonkwang Health Science University, Iksan 54538, Korea
}

\section{관절염 치료에 사용되는 한약재들의 항 염증 활성과 기전에 관한 연구}

\author{
김유현, 박 호 \\ 원광보건대학교 임상병리과
}

\begin{abstract}
When inflammatory reaction is in progress, the macrophages release inflammatory cytokines, such as interleukin-6 (IL-6), tumor necrosis factor- $\alpha$ (TNF- $\alpha$ ), and product inflammatory mediators, including inducible nitric oxide synthase (iNOS) and prostaglandin E2 (PGE2). We conducted this study to evaluate the anti-inflammatory efficacy on each water extract of Acanthopanacis cortex, Achyranthes radix, and Eucommiae cortex, and to investigate whether they inhibit the expression of pro-inflammatory cytokine. Acanthopanacis cortex, Achyranthes radix, and Eucommiae cortex were extracted with water and freeze-dried. Acanthoside D, 20-hydroxyecdysone, and pinoresinol diglucoside as an index material were analyzed by high-performance liquid chromatography (HPLC) to ensure that the components of each extracts were extracted well. RAW 264.7 cell line, stimulated with lipopolysaccharide (LPS) to cause an inflammatory response, was treated with each water extract at various concentrations to determine the anti-inflammatory efficacy. Then, the anti-inflammatory efficacy was confirmed by a nitric oxide (NO) assay, and the mRNA expression levels of pro-inflammatory cytokines were measured by real time PCR. As a result, the indicator materials were detected from each extract, and Acanthopanacis cortex water extract (ACWE) and Achyranthes radix water extract (ARWE) were shown to have a high activity than Eucommiae cortex water extract (ECWE) in NO assay. In Korea, traditionally it prescribed a combination of medicinal herbs. This study confirmed the anti-inflammatory response of these medicinal plants in arthritis and its synergistic effect when used in combination with western medicine.
\end{abstract}

Key words: Anti-inflammation, RAW 264.7, IL-6, iNOS, TNF- $\alpha$

This is an Open Access article distributed under the terms of the Creative Commons Attribution Non-Commercial License (http://creativecommons.org/licenses/by-nc/4.0) which permits unrestricted non-commercial use, distribution, and reproduction in any medium, provided the original work is properly cited.

Copyright @ 2016 The Korean Society for Clinical Laboratory Science. All rights reserved.
Corresponding author: Yoo-Hyun Kim Department of Clinical Laboratory Science, Wonkwang Health Science University, 514 Iksandae-ro, Iksan 54538, Korea Tel: 82-63-840-1218 Fax: 82-63-840-1219

E-mail: yhkim@wu.ac.kr

Received: July 11, 2016 Revised: July 29, 2016 Accepted: July 29, 2016

\section{서 론}

염증은 생체조직이 손상되었을 때 원래의 상태로 복구시키려는 방어작용 중 하나이다. 외부자극에 반응하여 혈관 내에서 serotonin, histamine, prostaglandin 등의 물질이 분비되어 혈관투과성이 증 대되면 염증반응이 진행된다[1]. 이때 작동되는 면역세포 중 대표
적인 세포가 대식세포이다[2]. 염증반응이 진행되면 대식세포에서 interleukin-6 (IL-6), tumor necrosis factor- $\alpha$ (TNF- $\alpha$ ) 등의 cytokine들이 발현되어 inducible nitric oxide synthase (iNOS), prostaglandin E2 (PGE2) 등의 염증 유발인자가 생성된다[3]. 이 러한 과정을 in vitro 실험에서 재현할 때, 주로 사용되는 물질이 lipopolysaccharide (LPS)이며, LPS는 그람 음성세균의 세포벽의 
구성성분 중 하나로 대식세포를 자극하여 염증 매개인자들을 발현 시키는 대표적인 물질이다[4]. 임상적으로 항 염증 작용에 주로 사 용되는 비 스테로이드성 진통소염제(non-steroidal anti-inflammatory drugs, NSAIDs)로는 asprin, magnesium salicylate, salsalate, diclofenac, etodolac, fenoprofen, flurbiprofen, ibuprofen, indomethacin, ketoprofen, meclofenamate, meloxicam, nabumetone, naproxen, piroxicam, sulindac, tolmetin, zaltoprofen, celecoxib 등 많은 종류가 있다. 그러나이 들 제제는 위장관 부작용, 간 독성, 신장 기능 저하, 인지 장애, 혈소 판 기능 저하, 알레르기성 피부 반응 등 부작용이 알려져 있다[5-7]. 특히 위장관 부작용이 가장 많이 보고되고 있으며 이는 소염제 특 성상 위장관 점막의 손상과 prostaglandin 생성의 억제가 원인이 다. 규칙적으로 NSAIDs를 처방 받는 환자의 약 $30 \%$ 가 위나 십이지 장의 궤양을 보이고 위출혈, 위 천공, 위장관 폐색 등의 부작용을 보 이기도 한다[8]. 최근의 염증분야 연구에서는 신령버섯 자실체의 메탄올 추출물이 LPS로 자극한 RAW 264.7 세포주에서 유의적인 항 염증 효능이 있다는 보고와 같이 염증 매개물질의 생산과 분비 를 억제하는 천연적인 소염물질을 찾는 경향을 보인다[9]. 이는 기 존 합성제제들 같은 소염제가 부작용을 보이기 때문이다[10]. 우리 나라의 전통적인 치료법은 여러 가지 한약재를 조합하여 처방하여 왔다. 이것은 한약재를 단독으로 사용하는 것보다 조합을 통하여 시너지 효과를 보이거나 질병치료에 불필요한 성분을 중화시키는 것을 목적으로 한 것이다. 관절염 치료에 주로 사용되어 왔던 오가 피(Acanthopanacis cortex), 우슬(Achyranthes radix), 두충 (Eucommiae cortex) 등도 이렇게 조합에 의해 사용되어 왔던 대 표적인 한약재들이다. 그러나 이들 한약재들의 치료제로서의 과학 적 근거는 매우 미흡한 실정이다. 본 연구에서는 마우스의 대식세 포주인 RAW 264.7 세포주에 LPS를 사용하여 염증을 유발하고, 한 약재인 오가피, 우슬, 두충의 항 염증 활성과 그의 기전을 확인하여 항 염증에 있어 시너지효능에 대한 근거를 마련하고자 한다.

\section{재료 및 방법}

\section{1. 오가피, 우슬, 두충의 추출}

건조 및 분쇄한 오가피, 우슬, 두충은 각각 $100 \mathrm{~g}$ 씩을 $1 \mathrm{~L}$ 의 증류 수에 넣은 후 $103^{\circ} \mathrm{C}$ 의 heating mentle로 3 시간 동안 교반하며 환 류 추출하고 여과하였다. 잔류액을 모두 감압 농축한 후 동결건조 하고 건조약재 대비 동결건조 분말로 하였다.

\section{2. 오가피, 우슬, 두충 추출물의 HPLC 분석}

오가피, 우슬, 두충을 추출하여 동결 건조시킨 분말을 $1 \mathrm{mg} / \mathrm{mL}$ 의 농도로 각각 에탄올에 녹여 초음파 추출 한 후 pore size $0.2 \mu \mathrm{m}$ 에 여과하여 high-performance liquid chromatography (HPLC; Agilent, Santa Clara, CA, USA)로 분석하여 유효성분 추출의 정도 를 확인 하였다. 각 약재에 대한 지표물질로 오가피는 acanthoside D, 우슬은 20-hydroxyecdysone, 두충은 pinoresinol diglucoside 를 모두 Sigma Aldrich (St. Louis, MO, USA)에서 구입하였으며, 사용된 유기용매는 모두 HPLC grade (J.T Baker, USA) 를 사용하 였다. 각 지표물질은 에탄올에 녹여 $1 \mathrm{~mL} / \mathrm{min}$ 의 농도로 만들고, 2 배수 희석을 통해 희석한 후 pore size $0.2 \mu \mathrm{m}$ 에 여과하여 HPLC로 분석하였다. Acanthoside $\mathrm{D}$ 의 분석은 $\mathrm{C} 18(4.6 \times 250 \mathrm{~mm}, 5 \mu \mathrm{m}$, Agilent) 컬럼을 사용하고, 컬럼 온도는 $40^{\circ} \mathrm{C}$, 검출기는 UV 210 $\mathrm{nm}$, 이동상으로는 $10 \%$ acetonitrile과 $30 \%$ acetonitrile을 사용하 여 gradient profile로 실시하였으며 유속은 $1 \mathrm{~mL} / \mathrm{min}$ 으로 하였 다. Gradient 조건은 Table 1과 같다[11]. 20-hydroxyecdysone 의 분석조건은 $\mathrm{C} 18(4.6 \times 250 \mathrm{~mm}, 5 \mu \mathrm{m}$, Agilent $)$ 컬럼을 사용하 고, 칼럼 온도는 $35^{\circ} \mathrm{C}$, 검출기는 UV $254 \mathrm{~nm}$, 이동상으로는 $100 \%$ acetonitrile과 물을 gradient profile로 하였고, 그 조건은 Table 2 와 같으며 유속은 $1 \mathrm{~mL} / \mathrm{min}$ 으로 실험하였다[12]. 두충의 지표물 질인 pinoresinol diglucoside는 대한약전의 두충 정량법으로 분 석하였다. C18 (4.6×250 mm, $5 \mu \mathrm{m}$, Agilent) 컬럼을 사용하고, 컬럼 온도는 $35^{\circ} \mathrm{C}$, 검출기는 UV $230 \mathrm{~nm}$, 이동상으로는 $0.1 \%$ formic acid의 물과 $100 \%$ acetonitrile을 사용하여 gradient profile로 실시하였고, 유속은 $1 \mathrm{~mL} / \mathrm{min}$ 으로 하였다. Gradient 조 건은 Table 3 과 같다. 오가피, 우슬, 두충 추출물에 대한 유효성분

Table 2. Gradient condition of 20-hydroxyecdysone

\begin{tabular}{|c|c|c|}
\hline \multirow{2}{*}{ Time (min) } & \multicolumn{2}{|c|}{ Mobile phase } \\
\hline & $10 \%$ Acetonitrile & $30 \%$ Acetonitrile \\
\hline 0 & 90 & 10 \\
\hline 5 & 85 & 15 \\
\hline 15 & 85 & 15 \\
\hline 20 & 90 & 10 \\
\hline 30 & 90 & 10 \\
\hline
\end{tabular}

\begin{tabular}{ccc}
\hline \multirow{2}{*}{ Time $(\min )$} & \multicolumn{2}{c}{ Mobile phase } \\
\cline { 2 - 3 } & Acetonitrile & Water \\
\hline 0 & 15 & 85 \\
8 & 15 & 85 \\
15 & 30 & 70 \\
30 & 30 & 70 \\
\hline
\end{tabular}


Table 3. Gradient condition of pinoresinol diglucoside

\begin{tabular}{|c|c|c|}
\hline \multirow{2}{*}{ Time (min) } & \multicolumn{2}{|c|}{ Mobile phase } \\
\hline & Acetonitrile & $0.1 \%$ Formic acid \\
\hline 0 & 5 & 95 \\
\hline 8 & 20 & 80 \\
\hline 15 & 20 & 80 \\
\hline 30 & 5 & 95 \\
\hline
\end{tabular}

은 각 지표물질의 농도 별로 얻어진 값으로 표준곡선을 그리고, 기 울기 값에 지표물질 분석조건과 같은 방법으로 얻어진 각 약재 추 출액의 peak 면적 값을 대입하여 계산하였다.

\section{3. 세포배양}

마우스의 대식세포인 RAW 264.7 세포주는 한국세포주은행 (No. 40071; KCLB, Seoul, Korea)에서 구입하여 사용하였다. 세 포는 10\% fetal bovine serum (FBS; Gibco, Rockville, MD, USA) 과 $1 \%$ antibiotic-antimycotic이 함유된 Dulbecco's minimum essential medium (DMEM; Gibco)을 사용하여 $37^{\circ} \mathrm{C}$ 와 $5 \% \mathrm{CO}_{2}$ 조건하에서 배양하였다.

\section{4. 오가피, 우슬, 두충 추출물의 NO assay}

RAW 264.7세포주가 활성화되면 NO를 생성하고 생성된 NO는 세포배양 배지에서 $\mathrm{NO}_{2}$ 의 형태로 존재한다. 그 양을 Griess 시약 [0.1\% N-(1-naphthyl) ethylene diamide dihydrochloride, 1\% sulfanilamide in $5 \%$ phosphoric acid; Sigma Aldrich]과의 반응 을 통해 측정하였다. RAW 264.7 세포주를 96 well plate에 $1 \times 10^{6}$ $\mathrm{cell} / \mathrm{mL}$ 의 농도로 분주하고 $37^{\circ} \mathrm{C}$ 와 $5 \% \mathrm{CO}_{2}$ incubator에서 24 시 간 동안 배양하였다. $1 \mu \mathrm{g} / \mathrm{mL}$ LPS (Sigma Aldrich)로 자극시킨 후 각각의 추출물을 다양한 농도 $(200,100,50,25 \mu \mathrm{g} / \mathrm{mL})$ 로 처리한 후 24 시간 동안 배양하였다. 상층액을 옮겨 담고 Griess 시약을 동 량 첨가한 후 $540 \mathrm{~nm}$ 의 microplate reader (Tecan, Australia)로 흡광도를 측정하여 $\mathrm{NO}_{2}$ 의 농도는 sodium nitrite의 표준곡선에 대 입하여 계산하였다. Griess 활성시험 후, 각 well에 MTT [3-(4, 5-dimethylthiazol-2-yl)-2, 5-diphenyltetrazolium bromide; Sigma Aldrich] 용액(최종 $0.5 \mathrm{~g} / \mathrm{mL}$ )을 첨가하고 4 시간 동안 $37^{\circ} \mathrm{C}$ 에서 배양하였다. 배지를 제거하고 dimethyl sulfoxide (DMSO; Samchun Chemical, Korea)를 첨가하여 생성된 formazan을 용 해시켰다. $570 \mathrm{~nm}$ 에서 흡광도를 측정하였고 control group과 비 교하여 세포생존율(\%)을 측정하였다.

\section{5. 역전사 중합반응}

$1 \mu \mathrm{g} / \mathrm{mL}$ 의 LPS로 자극된 RAW 264.7 세포주에 오가피, 우슬, 두충 각각의 추출물을 농도별 $(200,100,50,25 \mu \mathrm{g} / \mathrm{mL})$ 로 처리한 후 TRI regent (Sigma Aldrich)를 이용하여 총 cellular RNA를 추 출하였다. $1 \mu \mathrm{g}$ 의 RNA를 oligo-(dT)15 primer와 avian myeloblastosis virus (AMV) reverse transcriptase (Promega, USA)를 이용하여 역전사 반응을 진행하였다. $\mathrm{PCR}$ 은 $\mathrm{cDNA}, 0.2 \mathrm{mM}$ dNTP mixture (Promega, Madison, WI, USA), 10 pmol target gene-specific primers와 0.25 unit Taq DNA polymerase (Promega)를 섞은 후 GeneAmp PCR system 2400 (Applied Biosystems, Foster, CA, USA)을 이용하여 증폭하였다. 초기 denaturation을 $94^{\circ} \mathrm{C}$ 에서 4 분간 진행하고 $25 \sim 30$ cycle로 하였 으며 denaturation은 $94^{\circ} \mathrm{C}$ 에서 4 분, annealing 은 $55^{\circ} \mathrm{C}$ 에서 30 초, elongation은 $72^{\circ} \mathrm{C}$ 에서 30 초, extension은 $72^{\circ} \mathrm{C}$ 에서 5 분간 진행하였다. PCR산물을 확인하기 위하여 $2 \%$ agarose gel로 전기 영동 하였고 SYBR-Gold (Molecular Probes, Eugene, OR, USA) 와 영상분석장치를 이용하였다.

\section{6. 통계}

모든 실험은 최소 3회 반복하였으며 데이터는 평균ㅍㅍㅍ준편차 로 표시하였다. 통계처리는 analysis of variation (ANOVA) 방식으 로 SPSS 버전 18.0 (IBM, Armonk, NY, USA)을 사용하였다.

\section{결 과}

\section{1. 오가피, 우슬, 두충의 추출}

오가피, 우슬, 두충을 열수로 환류 추출하고 여과 후 동결 건조하 여 분말의 무게를 측정하였다. 각각 $19.3 \pm 1.27 \%, 38.2 \pm 1.49 \%$, $14.2 \pm 0.76 \%$ 의 수율을 보였으며 HPLC 분석결과 모든 약재에서 각각의 지표성분이 검출되었다. 우슬의 20-hydroxyecdysone과 오가피의 acantoside $\mathrm{D}$ 는 지표성분의 검출이 어렵지 않았으나 두 충의 pinoresinol diglucoside는 분석이 용이하진 않았지만 HPLC 의 UV 검출기로 가능하였다(Fig. 1).

\section{2. 오가피, 우슬, 두충 추출물의 NO assay}

$\mathrm{NO}$ 는 LPS의 자극으로 인하여 활성화되는 것으로 $\mathrm{NO}$ 합성효소 에 의하여 생성된다. RAW 264.7 대식세포주에 LPS로 자극시키면 다량의 $\mathrm{NO}$ 를 생성하며 이에 의한 세포 독성은 염증반응, 종양발생 등에도 관여한다[13]. 본 연구에서는 오가피, 우슬, 두충 각각의 추 출물에 대하여 $\mathrm{NO}$ assay를 진행하고 항 염증 활성을 농도 별로 비 

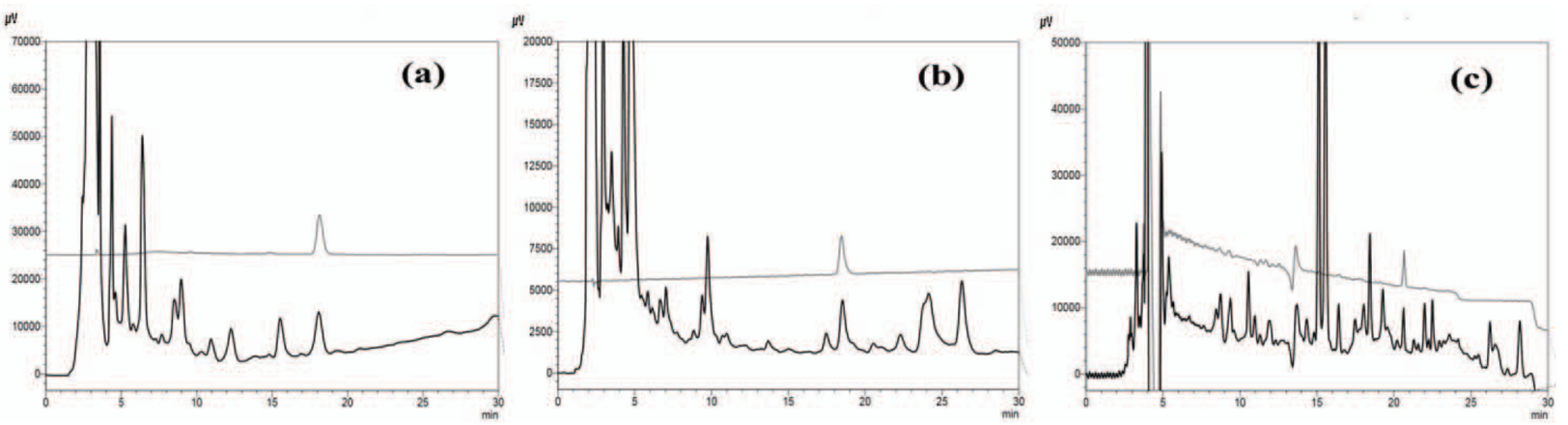

Fig. 1. Analysis of the indicator components for each of the medicines. (a) Acanthoside D and ACWE, (b) 20-hydroxyecdysone and ARWE, (c) Pinoresinol diglucoside and ECWE. The chromatogram of the standard material above is gray and chromatogram of the following medicines is black. Abbreviation: ACWE, Acanthopanacis cortex water extract; ARWE, Achyranthes radix water extract; ECWE, Eucommiae cortex water extract.

교하였다. 전체적으로는 샘플의 농도가 높아질수록 발생되는 $\mathrm{NO}$ 의 량이 감소하는 것으로 보아 농도 의존적으로 항 염증 효능이 있 다는 것을 확인할 수 있었다. 그러나 우슬, 오가피에 비하여 두충은 유의적으로 낮은 활성을 보였다(Fig. 2a). 실험에 사용된 오가피, 우 슬, 두충 추출물의 농도 별 세포독성을 확인한 MTT assay에서는 모 든 농도에서 $85 \%$ 이상의 생존율을 보여 각 추출물은 RAW 264.7 세포주에서 독성을 나타내지 않음을 확인하였고 NO assay의 결과 가 세포사멸에 의한 것이 아님을 확인 할 수 있었다(Fig. 2b).

\section{3. 역전사 중합반응}

오가피, 우슬, 두충 추출물 각각의 항 염증 기전을 확인하기 위하 여 iNOS, TNF- $\alpha$, IL-6의 mRNA 발현량을 real time PCR로 확인 하였다. iNOS와 IL-6의 억제율은 NO를 생성시키는 pathway에 속하는 pro-inflammatory cytokine이기에 $\mathrm{NO}$ 와 비슷한 경향으 로 발현됨을 확인하였다(Fig. 3a,c). 그러나 TNF- $\alpha$ 억제율에서는 $\mathrm{NO}$ assay에서 낮은 항 염증 활성을 보인 우슬 추출물이 가장 높은 활성을 보였다(Fig. $3 \mathrm{~b})$. 오가피, 우슬과 두충은 서로 다른 기전으로 항 염증 활성을 이끌었으므로 오가피와 두충, 또는 우슬과 두충의 조합은 in vivo 또는 임상실험에서 충분한 시너지를 보일 가능성이 높았으며 이들의 조합은 양질의 천연 소염제를 개발하는 데에 충분 한 가능성을 시사하였다.

\section{고 찰}

신체에 염증이 발생되면 면역조절의 중요한 인자인 cytokine들 은 감염에 대한 숙주반응으로서 발현된다[14]. NO를 형성하는 NO synthase (NOS)에는 endothelial NOS (eNOS), neuronal NOS (nNOS) 그리고 iducible NOS (iNOS) 세가지가 있다. 이중 $\mathrm{eNOS}$ 와 $\mathrm{nNOS}$ 는 상피세포와 신경에 존재하여 정상적인 생리기능 (a)

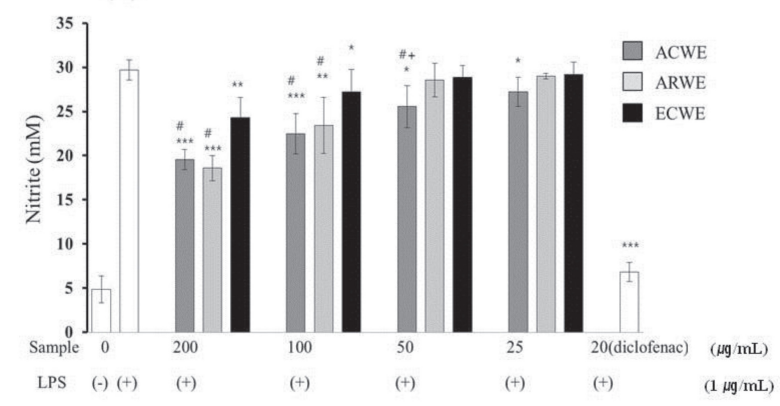

(b)

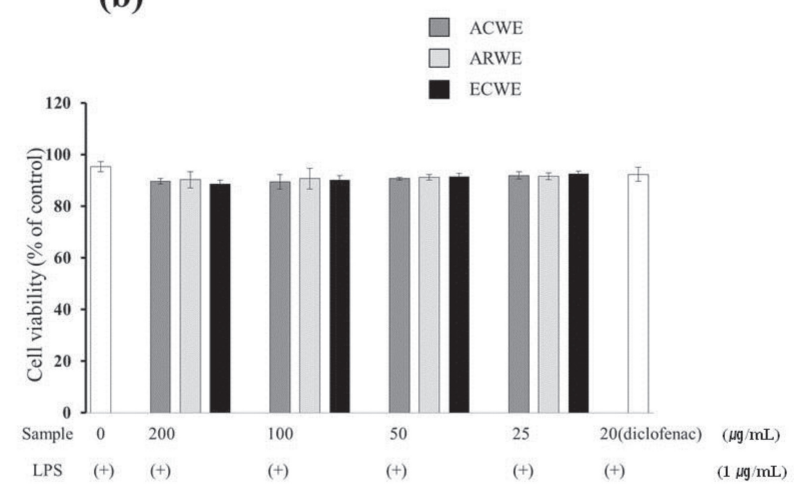

Fig. 2. Inhibitory effects of each of the medicine hot water extracts on LPS-induced NO production in macrophage cells. (a) RAW 264.7 cells were stimulated with $1 \mu \mathrm{g} / \mathrm{mL}$ LPS in a presence or absence of ACWE, ARWE, ECWE. (b) The cell viability was measured by MTT method. After $20 \mathrm{~h}$, cultured media were collected and analyzed nitrite concentration using Griess reaction. The values are means \pm SD. ${ }^{* * *} p<.0001$, ${ }^{* *} p<0.001,{ }^{*} p<0.05$ compared to the control (LPS treated group). ${ }^{+} p<0.05$ compared to ECWE. ${ }^{\#} p<0.05$ compared to ARWE. ${ }^{p} p<0.05$ compared to ACWE. Abbreviation: ACWE, Acanthopanacis cortex water extract; ARWE, Achyranthes radix water extract; ECWE, Eucommiae cortex water extract. 


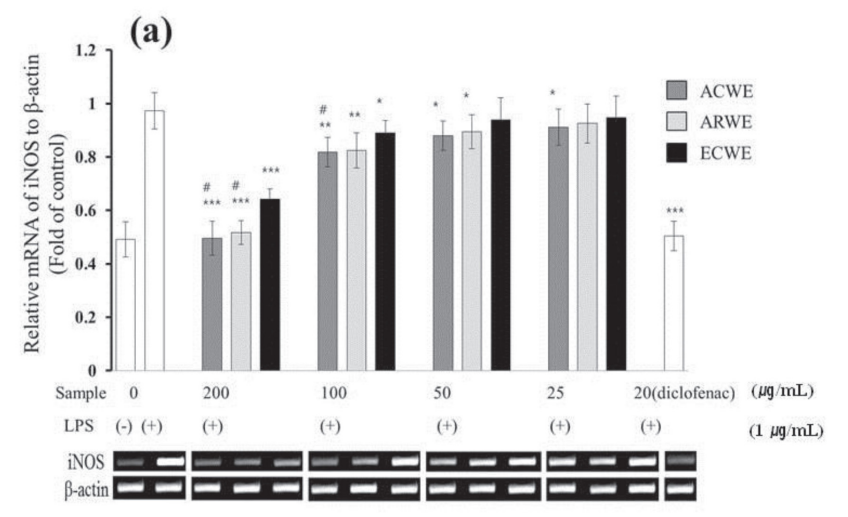

(b)

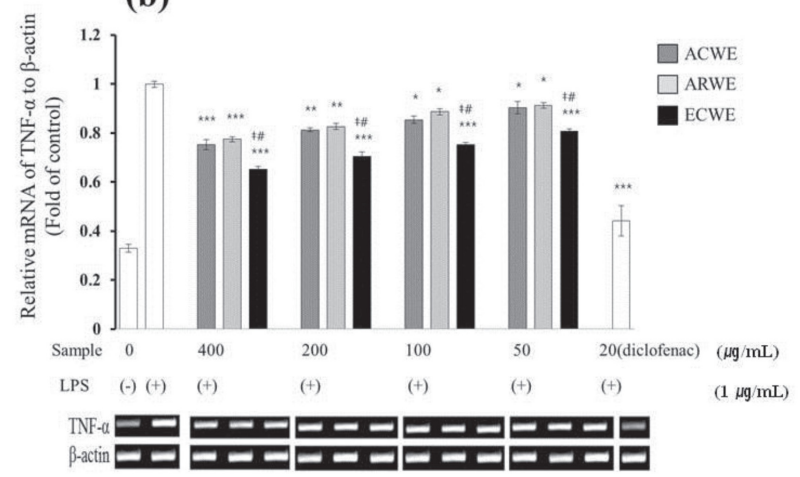

(c)

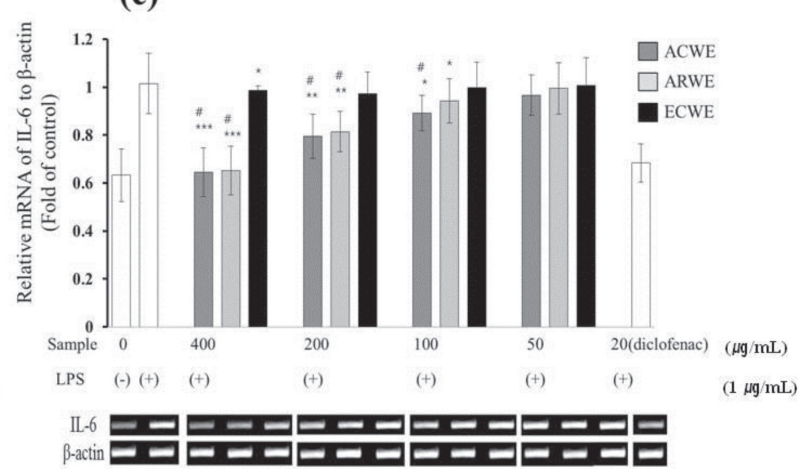

Fig. 3. Effects of ACWE, ARWE, ECWE on LPS-induced pro-inflammatory cytokine mRNA expression in macrophage cells. (a) The amount of iNOS was measured in proportion to the $\beta$-actin and electrophoresis. (b) The amount of TNF- $\alpha$ was measured in proportion to the $\beta$-actin and electrophoresis. (c) The amount of IL-6 was measured in proportion to the $\beta$-actin and electrophoresis. RAW 264.7 cells were treated with LPS $(1 \mu \mathrm{g} / \mathrm{mL})$ and ACWE, ARWE, ECWE for $4 \mathrm{~h}$. Total RNA was isolated and further analyzed by RT-PCR. Data were representative of three separated experiments. $\beta$-actin was used as an internal standard. The values are means \pm SD. ${ }^{* \star *} p<.0001,{ }^{\star *} p<0.001,{ }^{*} p<0.05$ compared to the control (LPS treated group). ${ }^{+} p<0.05$ compared to ECWE. ${ }^{\#} p<0.05$ compared to ARWE. ${ }^{\ddagger} p<0.05$ compared to ACWE. Abbreviation: ACWE, Acanthopanacis cortex water extract; ARWE, Achyranthes radix water extract; ECWE, Eucommiae cortex water extract.

을 조절하기 위해 지속적으로 $\mathrm{NO}$ 를 소량씩 생성한다. 하지만 iNOS는 대식세포나 혈관세포에서 $\mathrm{NO}$ 를 과량 생성하여 면역질환 및 패혈증을 야기시킨다[15]. IL-6은 항암효과와간세포의 단백질 합성을 유도하고 조직 손상에 대한 발열반응을 초래하며, IL-1과 협동적으로 작용하여 $\mathrm{B}$ 세포에서의 면역 글로불린 유리를 촉진시 키고 흥선세포와 T세포의 분화에 관여한다[16,17]. TNF- $\alpha$ 는 주로 대식세포에서 생성되어 면역반응을 증가시키고, 혈관 성장 자극, 에너지유출 증가, 감염, 염증과 창상 치유의 촉진과 종양에 항 증식 작용을 한다[18]. 본 연구에서 시험된 염증성 cytokine들은 염증기 전에서 지금까지 보고되어 온 pathway중 거의 마지막 단계이다. 본 연구에서 이러한 cytokine의 발현량이 차이가 있다는 것은 오가 피, 우슬, 두충의 추출물들이 항 염증효능을 가짐에 있어서 염증을 차단시키는 경로가 다르다는 것을 의미한다. 두충의 경우에는 $\mathrm{TNF}-\alpha$ 를 유의적으로 차단시키는 역할을 하였고 오가피, 우슬은 주로 $\mathrm{iNOS}$ 를 차단시키는 역할을 했다. 위 결과를 유추해 볼 때, 오
가피와 두충, 또는 우슬과 두충이 조합된 처방은 각각의 한약재의 약효뿐 아니라 시너지 효과를 보일 수 있다는 것을 알 수 있다. 오가 피는 전통적으로 중국과 우리나라에서 관절염 치료에 사용되어온 식물로 최근에는 국내에서 많이 자생하고 있는 오가피에 대한 생리 활성 및 가공 적합성에 대한 다양한 연구가 진행되고 있다. 오가피 의 성분은 stigma sterol, campesterol, $\beta$-sitosterol 등의 sterol, sesamin과 savinin, chlorogenic acid, sesquiterpene 등으로 이 루어져 있으며 특히 오가피의 뿌리와 줄기 부분은 대표적인 생리활 성 성분으로 알려져 있는 eleutheroside E, eleutheroside B를 다 량 함유하고 있다고 보고되었다[19]. 우슬은 아시아지역에 광범위 하게 분포하는 다년초 식물뿌리로서 보고된 약리작용으로 부종, 진 통작용, 혈압강하, 이뇨작용, 류머티스 등 면역반응에 대한 민간요 법으로 널리 사용하였다[20,21]. 우슬에는 항 보체 효과를 갖는 oleanolic acid계 saponin이 함유되어 있으며 중추 미각계의 신호 전달을 억제하는 $\gamma$-aminobutyric acid 등이 알려져 있다[22]. 우 
슬은 그 밖에도 steroid 계열인 $\beta$-sitosterol, stigmasterol, stigmasterol glycoside, rubrosterone 등과 triterpenoid 계열의 inkosterone과 같은 화합물들이 보고 되어있다[23]. 두충은 지금 까지 알려진 오래된 약초 중의 하나로 phytochemical이 많이 들어 있는데 대표적인 것이 polyphenolics pyrogallol, protocatechuic acid, coumaric acid, chlorogenic acid, triterpone, 그리고 quercetin, kaempherol, astragalin을 함유한 flavonoid 등이 있 다[24]. 이와 같이 두충에는 배당체, alkaloid, pectin, 지질, 유기 산, 당류 및 vitamin C 등과 phenol성 화합물이 함유되어 있어 혈 압강하 작용, 이뇨작용과 항 당뇨 활성, cholesterol 저하 및 비만 방지의 효과가 있는 것으로 알려져 있다[25]. 오가피, 우슬, 두충은 한방에서는 관절염치료에 다 빈도로 사용되는 약재이다. 본 연구는 이러한 약재들의 항 염증 활성과 기전에 대한 연구를 하였으며, 그 결과 각 약재들이 항 염증활성이 있음을 확인하였고, 관여하는 기 전을 이해함으로 한약재의 조합을 통하여 치료에 시너지 효과를 연 구하는 데에 기여할 수 있기를 바란다.

\section{요 약}

대식세포에서 염증반응이 진행되면, interleukin-6 (IL-6), tumor necrosis factor- $\alpha$ (TNF- $\alpha$ ) 등의 cytokine들이 발현되어 inducible nitric oxide synthase (iNOS), prostaglandin E2 (PGE2) 등의 염증유발인자가 생성된다. 오가피, 우슬, 두충 각각의 추출물이 어느 정도의 항 염증 효능을 보이며 어떤 pro-inflammatory cytokine의 발현을 억제하는지에 대한 연구를 진행하였 다. 오가피, 우슬, 두충은 물 추출하고 동결 건조시켰다. 각각의 추 출물의 구성 성분들이 잘 추출되었는지 확인하기 위하여 지표물질 인 acanthoside D, 20-hydroxyecdysone, pinoresinol diglucoside를 HPLC로 분석하였다. 항 염증 효능을 확인하기 위하여 lipopolysaccharide (LPS)로 RAW 264.7 세포주를 자극하여 염증 반응을 일으킨 상태에서 각각의 추출물을 농도 별로 처리하고 $\mathrm{NO}$ assay를 통해 항 염증 효능을 확인하였으며 real time PCR로 pro-inflammatory cytokine들의 발현량을 측정하였다. 결과적 으로 각각의 추출물은 지표성분들이 검출되었으며 오가피와 우슬 이 두충보다 NO assay에서 높은 활성을 보였다. Cytokine 발현량 측정에서는 오가피와 우슬은 $\mathrm{NOSS}$ 와 IL-6의 발현을 억제하였고, 우슬은 TNF- $\alpha$ 의 발현을 억제하였다. 우리나라는 전통적으로 약 재를 조합하여 처방하여 왔다. 본 연구는 관절염에 전통적으로 사 용해 오던 약재들이 어떤 기전에 의하여 항 염증 반응을 보이는지 확인하고 이들을 조합하여 사용하였을 때 어떤 근거에 의하여 시너 지 효능을 보이는지 확인하였다.
Acknowledgements: 이 논문은 2016년도 원광보건대학교 교내 연구비 지원으로 이루어졌으며 지원에 감사드립니다.

Funding: None

Conflict of interest: None

\section{References}

1. Song JH, Kim MJ, Kwon HD, Park IH. Antimicrobial activity of fractional extracts from Houttuynia cordata root. J Kor Soc Food Sci Nutr. 2003;32:1053-1058.

2. Higuchi M, Higashi N, Taki H, Osawa T. Cytolytic mechanism of activated macrophages. Tumor necrosis factor and L-arginine-dependent mechanism acts as synergistically as the major cytolytic mechanism of activated macrophages. J Immunol. 1990;144:1434-1441.

3. Stock M, Schilling M, Burkhardt K, Prestel R, Abendroth D, Hammer C. Production of pro-inflammatory cytokines and adhesion molecules in ex-vivo xenogeneic kidney perfusion. Transpl Int. 1994;7:647-649.

4. Kwon PS. Comparison of quantitative endotoxin against 5 species of Enterobacteriaceae. Korean J Clin Lab Sci. 2016;48: 124-129.

5. Bloom BS. Direct medical costs of disease and gastrointestinal side effects during treatment for arthritis. Am J Med. 1988; 84:20-24.

6. Bloom BS. Risk and cost of gastrointestinal side effects associated with nonsteroidal anti-inflammatory drugs. Arch Intern Med. 1989;149:1019-1022.

7. Fries JF. NSAIDS gastropathy: The second most deadly rheumatic disease epidemiology and risk appraisal. J Rheumatol. 1991;18:6-10.

8. Roujeau JC, Kelly JP, Naldi L, Rzany B, Stern RS, Anderson T, et al. Medication use and the risk of Steven-Johnson syndrome or toxic epidermal necrolysis. N Engl J Med. 1995;333:1600-1607.

9. Yoon KN, Jang HS, Jin GH. Antioxidant, anti-diabetic, anti-cholinesterase, and nitric oxide inhibitory activities of fruiting bodies of Agaricus brasiliensis. Korean J Clin Lab Sci. 2015;47:194-202.

10. Lee MH, Jeong JH, Jeong MS, Chang SH, Her E. Anti-inflammatory function of the Sophora japonica extract rutin: The inhibitory effect of rutin of Korean Sophora japonica on the productions of $\mathrm{NO}$ and TNF alpha from mouse peritoneal macrophages. Korean J Medicinal Crop Sci. 2010;18:105-112.

11. Hong SS, Hwang JS, Lee SA, Hwang BY, Ha KW, Ze KR, et al. Isolation and quantitative analysis of acanthoside $\mathrm{D}$ from Acanthopanacis cortex. Kor J Pharmacogn. 2001;32:316-321.

12. Son KH, Hwang JH, Lee SH, Park JH, Kang SJ, Chang SY, Lee KS. Isolation and quantitative determination of 20-hydroxyecdysone from Achyranthes radix. Kor J Pharmacogn. 1999;30:335-339.

13. Weisz A, Cicatiello L, Esumi H. Regulation of the mouse inducible-type nitric oxide synthase gene promoter by interferon- $\gamma$, bacterial lipopolysaccharide, and NG-monomethyl-Larginine. Biochem J. 1996;316:209-215.

14. Lee SJ, Kim JK. Inflammation and insufficient or disordered sleep. Korean J Clin Lab Sci. 2015;47:97-104. 
15. Garcia X, Stein F. Nitric oxide. Semin Pediatr Infect Dis. 2006;17:55-57.

16. Dinarello CA, Endres S, Meydani SN, Meydani M, Hellerstein MK. Interleukin-1, anorexia, and dietary fatty acids. Ann N Y Acad Sci. 1990;587:332-338.

17. Liu M, Li J, Kong F, Lin J, Gao Y. Induction of immunomodulating cytokines by a new polysaccharide-peptide complex from culture mycelia of Lentinus edodes. Immunopharmacology. 1998;40:187-198.

18. Nedwin GE, Svedersky LP, Bringman TS, Palladino MA Jr, Goeddel DV. Effect of interleukin 2, interferon-gamma, and mitogens on the production of tumor necrosis factors alpha and beta. J Immunol. 1985;135:2492-2497.

19. Choi JM, Ahn JB. Functional properties of 50\% methanol extracts from different parts of Acanthopanax sessiliflorus. Korean J Food Sci Technol. 2012;44:373-377.

20. Han SB, Lee CW, Yoon YD, Kang JS, Lee KH, Yoon WK, et al. Prevention of arthritic inflammation using an oriental herbal combination BDX-1 isolated from Achyranthes bidentata and Atractylodes japonica. Arch Pharm Res. 2005;28:902-908.

21. Bang SY, Kim JH, Kim HY, Lee YJ, Park SY, Lee SJ, et al. Achyranthes japonica exhibits anti-inflammatory effect via $\mathrm{NF}-\mathrm{\kappa B}$ suppression and $\mathrm{HO}-1$ induction in macrophages. J Ethnopharmacol. 2012;144:109-117.

22. Kim MW, Park HO, Pahng MS, Park SW, Kim SH, Kim SH, et al. Effect of gamma-aminobutyric acid on the gustatory nucleus tractus solitaries in rats. Int J Oral Biol. 2005;30:91-98.

23. Hahn DR, Lee MW. Studies on the constituents of Achyranthes radix (I). J Parm Soc Korea. 1991;35:457-460.

24. Park SA, Choi MS, Jung UJ, Kim DJ, Park HM, Park YB, et al. Eucommia ulmoides oliver leaf extract increases end ogenous antioxidant activity in type 2 diabetic mice. J Med Food. 2006; 9:474-479.

25. Han SH. Effects Eucommia ulmoides oliver tea extract on aluminum accumulation rate and tissue function in aluminum-administered rat. Korean J Food Culture. 2010;25:839-846. 